\title{
Cytogenetic and Ultrastructural Studies of Effects of Antifungal Drug, Fluconazole on Liver of New-born Mice
}

\author{
Azza Attia ${ }^{1,}$, , Cecil Matta ${ }^{1}$, Reda Elmazoudy ${ }^{2,3}$, Zeinab Elhenshery ${ }^{4}$ \\ ${ }^{1}$ Zoology Department, Faculty of Science, Alexandria University, Alexandria, Egypt \\ ${ }^{2}$ Biology Department, College of Science, Imam Abdulrahman Bin Faisal University, Dammam, Saudi Arabia \\ ${ }^{3}$ Basic and Applied Scientific Research Center, Imam Abdulrahman Bin Faisal University, Dammam, Saudi Arabia \\ ${ }^{4}$ Faculty of Science, Omar Al-Mokhtar University, Tripoli, Libya
}

\section{Email address:}

azzaaattia@hotmail.com (A. Attia), azza.attia@alexu.edu.eg (A. Attia)

${ }^{*}$ Corresponding author

\section{To cite this article:}

Azza Attia, Cecil Matta, Reda Elmazoudy, Zeinab Elhenshery. Cytogenetic and Ultrastructural Studies of Effects of Antifungal Drug, Fluconazole on Liver of New-born Mice. Biomedical Sciences. Vol. 7, No. 1, 2021, pp. 1-9. doi: 10.11648/j.bs.20210701.11

Received: August 26, 2020; Accepted: September 14, 2020; Published: January 12, 2021

\begin{abstract}
As a potent antifungal drug, fluconazole clinically used to eradicate both systemic and superficial mycoses resulting in hepatotoxicity. The objective of the current study was to evaluate hepatotoxicity and genotoxicity in newborn male mice. Mice were treated orally with $0.5 \mathrm{ml}$ fluconazole doses of $(0,25,50$, and $100 \mathrm{mg} / \mathrm{kgbw})$ per day for five consecutive weeks. Micronucleus test, chromosomal aberrations in bone marrow cells, histopathological investigation and DNA fragmentation in the liver tissue was done. Micronuclei are significantly noticed in bone marrow cells of mice given 50 and $100 \mathrm{mg} / \mathrm{kgbw}$ fluconazole however, there is no effect on the genotoxicity induced by $25 \mathrm{mg} / \mathrm{kgbw}$ dose of fluconazole. A dosedependent and significant increase in structural and numerical chromosomal aberrations were detected in the 50 and 100 $\mathrm{mg} / \mathrm{kgbw}$ fluconazole-treated group but a $100 \mathrm{mg} / \mathrm{kg}$ was highly significant. The chromosomal aberrations were manifested in hypoploidy, deletion, centric fusion and stickiness. Besides, hepatocellular massive infiltration, cytoplasmic vacuolation, congestion and dilatation in the central veins were seen in 50 and $100 \mathrm{mg} / \mathrm{kgbw}$ fluconazole. Interestingly, 25mg/kgbw fluconazole-treated mice showed mild hepatocellular degeneration. Consequently, these findings confirmed that fluconazole to a greater extent was a potent hepatotoxic drug in vivo in newborn mice.
\end{abstract}

Keywords: Fluconazole, Genotoxicity, Micronucleus, Chromosomal Aberration, Hepatotoxicity

\section{Introduction}

Environmentally, many species of fungi are associated with human disease. Fungal infections cause a certain risk for many populations. Any person can expose to the fungal source such as spores on surfaces or in the air, soil, or bird droppings [1].

Fungi as a member of a large group of eukaryotic organisms could produce biologically active compounds called mycotoxins or secondary metabolites which can cause disease and death in human beings and other vertebrates [2]. During neonatal life, fungal infections may cause considerable morbidity and mortality; particularly in premature neonates [3]. It is found that a delay in antifungal therapy could increase mortality rates to a hundred percent.
Furthermore, inflammation and tissue damage are triggered by fungal infection [4].

Over the last few years, the number of antifungal drugs, azoles, has constantly been increasing [5], where they are used in therapy and management of superficial and systemic mycoses [6]. Fluconazole is one of azole drug group which has antifungal activity and may eradicate both superficial and invasive fungal infection [7]. Also, it has many other attributes like antiparasitic characters, initiates wound healing, and declines the development of organ dysfunction in human [8]. Besides, fluconazole can prevent the neonatal candidiasis in the newborn infants which have very low body weight [3]. Leonart et al. [9] estimated the safety and efficacy of different doses of fluconazole used for invasive prophylaxis of fungal infection in neonates. They found that 
$3 \mathrm{mg} / \mathrm{kg}$ of it could be recommended for Candida prophylaxis in neonates. Additionally, Lollis and Bradshaw [10] found that Candida spp may cause invasion, colonized and make few signs and symptoms, leading to death. Fluconazole could also estimate hepatotoxicity and cause an increased incidence of hepatocellular adenomas in male rats treated orally for 2 years at doses of 5 and $10 \mathrm{mg} / \mathrm{kg} /$ day [11]. Peffer et al. [12] found that some conazoles fungicide (as a class of $N$-substituted azole antifungal drugs) are carcinogens, reproductive toxins, and induce hepatomegaly and increase hepatic cell proliferation in mice. Acute liver injury was uncommon in treatment with fluconazole [13]. Hepatotoxicity caused by fluconazole is caused due to its ability to alter sterol synthesis, or it may be a potent inhibitor of a cytochrome P450 enzyme. This can lead to a higher increase in plasma levels that are metabolized by CYP3A4, particularly the statins and cyclosporine.

Genotoxicity test such as micronucleus assay is biomonitoring of human exposure to genotoxic agents [14]. When the chromosome is failed to be included into daughter nuclei after mitosis, micronuclei are arising as fragments of chromatin containing bodies. This provides an indirect measure of the induction of structural chromosomal aberrations [15]. The micronucleus test, in vivo, is a method devised primarily for screening chemicals for chromosome breakage, and it also detects the effects on the spindle apparatus [16]. In a dose-dependent, fluconazole was found to enhance micronuclei at a statistically significant level. Yuzbasioglu et al. [17] found that fluconazole initiates structural chromosomal aberrations such as sister chromatid union, chromatid, chromosome breaks, dicentric chromosomes, chromatid exchange and fragments. Chromosomal breakage may lead to abnormalities of chromosomal segregation at mitosis [18]. Also, it could induce numerical chromosomal aberration such as polyploidy. Holeckova et al. [19] detected chromosomal aberrations in cattle lymphocyte cells that were cultured in vitro after conazole fungicide treatment. There are many documented studies in the literature of azole-induced hepatotoxicity. Consequently, due to the adverse effect that fluconazole may cause, the present study is a continuation of hepatotoxicity with a focus on the genotoxicity and histopathological evaluation as a main role of fluconazole in hepatocellular alterations.

\section{Experimental}

\subsection{Chemicals}

Fluconazole 2-(2, 4-di fluorophenyl)-1, 3-bis (1H-1, 2, 4triazole-1-yL)-2-propanol was purchased from the pharmacy under the international trade name: Diflucan capsule (50 mg fluconazole/ capsule). It was manufactured by Pfizer, Egypt, under Authority of Pfizer INC., U.S.A. Three stock solutions of different doses were well prepared according to the equivalent daily prescribed dose for a human. Fluconazole was liquefied in saline solution $(0.9 \% \mathrm{NaCl})$.

\subsection{Animals and Doses}

One-hundred and sixty newly weaned male mice (three weeks old and weighing nearly 6-8g) were received from the Faculty of Agriculture, Alexandria University, Alexandria, Egypt. Mice were put in the usual type of stainless-steel cages (5 mice/cage), which were scribed day by day continuously. Mice were modified to the controlled environmental conditions at room temperature of $25 \pm 2^{\circ} \mathrm{C}$, relative humidity $60 \pm 10 \%$, and given free access of food (milk, wheat, bread) and tap water ad libitum. These acclimated male mice were divided into four groups of approximately equal in body weights (15 mice/each). They were assigned to three experimental groups and one control. Mice of each experimental group were administered orally at morning between 9 and 11 am with $0.5 \mathrm{ml}$ fluconazole at doses of $25,50,100 \mathrm{mg} / \mathrm{kgbw} /$ day, for five consecutive weeks. The control mice were administered daily only with $0.5 \mathrm{ml}$ saline solution in the same manner.

Experimental procedures were achieved in conformation with principles of laboratory animal care approved by the institutional animal care and use committee Alexandria University, Alexandria.

\subsection{Clinical Examination}

Carefully, all mice were screened for signs of clinical toxicity examinations daily for morbidness, mortality, stereotypy, or behavior throughout the experimental period.

\subsection{Bone Marrow Processing for Genotoxicity Analysis}

Twenty-four hours after administration of the last dose of fluconazole, and two hours before euthanasia and sacrifice, mice were administered intravenously $0.5 \mathrm{mg} / \mathrm{kgbw}$ Colchicines [20]. Surgically the femora of each mouse were aseptically anatomized. The contents of the bone marrow were collected from the proximal extremity of each sectioned femur by flushing in $0.075 \mathrm{M} \mathrm{KCl}$, incubated at $37^{\circ} \mathrm{C}$ for 25 min., and centrifuged at $2000 \mathrm{rpm}$ for $10 \mathrm{~min}$. The homogenous suspension of bone marrow cells recentrifuged at $1,500 \mathrm{rpm}$ for $10 \mathrm{~min}$ and then the cellular pellets were washed in saline solution. Thereafter, the cellular pellets of bone marrow were fixed in acetic acid: methanol (1:3 respectively). This process was repeated four times at an interval of $15 \mathrm{~min}$ each. The slides of best-spread metaphase cells were smeared, dried at $25^{\circ} \mathrm{C}$, and stained with $5 \%$ Giemsa stain for 3-5 min followed by removing the excess stain in distilled water to distinguish polychromatic erythrocytes (PCEs). Nucleated PCEs were examined at 1000x under light microscopy in 180 metaphases for each animal to a total of 6000 metaphases for each treatment and control group and counted. The number and percentage of PCEs were determined. The type and frequency of structural and numerical chromosomal aberrations in the different groups were observed, photographed and tabulated. We estimated ten mice for both the experimental and control group. Three replicates of each endpoint were applied for all groups. 


\subsection{DNA Analysis}

The genomic DNA was isolated from the liver tissue using spin column method Axy Prep Multisource Genomic DNA Mini-Prep Kit obtained from Axy gen Biosciences, Union City, CA94587 USA. Gel electrophoresis by Sub-Cell GT electrophoresis systems (BIO-RAD, USA) was stained by Ethidium bromide [21].

\subsection{Light Microscopic Methods}

Both control and experimental treated mice were killed by cervical dislocation under anaesthetic conditions. Macroscopically, the abdominal cavities were exposed and examined, and small pieces of the liver tissues were dissected out immediately from the peripheral areas of the two lobes and were rinsed overnight in Bouin's solution. Thereafter, fixed tissue was dehydrated and embedded in paraffin wax. Serial liver sections were cut at $5 \mu \mathrm{m}$ thick, stained by haematoxylin-eosin (H\&E), cleared by xylene and were examined by the light microscopy for histopathological examination [22].

\subsection{Electron Microscopic Methods}

Very small slices from the periphery of livers of both control and fluconazole-treated mice were dissected out and fixed immediately in 2\% 4F1G (4\%formaldhyde and $1 \%$ glutaraldehyde), then put in $0.1 \mathrm{M}$ phosphate buffer, $\mathrm{pH}=7.4$ at $4^{\circ} \mathrm{C}$ for around $1 \mathrm{~h}$, then rinsed in $0.1 \mathrm{M}$ phosphate buffer (pH 7.4). This was completed by post-fixation using $1 \%$ buffered $\mathrm{OsO}_{4}$ (osmium tetroxide) for $1-2 \mathrm{~h}$ at $4{ }^{\circ} \mathrm{C}$, then the specimens were cleaned with phosphate buffer for several times for $30 \mathrm{~min}$, dehydrated in ascending grades of ethanol concentration. The liver tissues were then treated with propylene oxide and embedded in a mixture of 1: 1 of EponAraldite. Specimens were put in pre-dried gelatine capsule (dried in the oven at $37^{\circ} \mathrm{C}$ for $1 \mathrm{~h}$ before use) [23]. Ultrathin sections of such specimens were cut in serial sections with a glass knife on LKB ultra-microtome, mounted on 200 mesh naked copper grids, doubled stained with uranyl acetate and lead citrate.

\subsection{Statistical Analysis}

Statistical analysis was estimated using the SPSS software package version 17.0. All data were exhibited as the mean \pm Standard deviation $(X \pm$ S.D. $)$ and were analyzed statistically using one-way analysis of variance (ANOVA). All tests were performed at a significant level of probability value $P \leq 0.05$. The significance was determined by Fisher's exact probability test (F-test) and resulted in F-value which can be compared with the tabulated value.

\section{Results}

\subsection{Oral Toxicity of Fluconazole}

No scheduled mortality and all mice in the control and fluconazole-treated groups remained alive until the last experimental days of the study. However, mice were given 50 and $100 \mathrm{mg} / \mathrm{kgbw}$ of fluconazole showed signs of stereotypical behavior, hypoactivity, failed to respond to external stimuli in addition to hair loss. On the other hand, all animals in $25 \mathrm{mg} / \mathrm{kgbw}$ group exhibited a state of being free from illness or injury to the final point of the experiment compared to controls.

\subsection{Genotoxicity Findings}

\subsubsection{Polychromatic Erythrocytes}

The micronucleus results revealed significant increases in the percentage of polychromatic erythrocytes (PCEs) with micronuclei in the bone marrow cells of mice treated with 50 and $100 \mathrm{mg} / \mathrm{kgbw} / \mathrm{day}$ fluconazole (Table 1). These findings suggest the presence of mutagenicity for fluconazole regarding the 50 and $100 \mathrm{mg} / \mathrm{kgbw}$ dose. In contrast, 25 $\mathrm{mg} / \mathrm{kgbw}$ dose exhibited no mutagenic activity. So, these findings indicate that fluconazole can induce genotoxic effects in the bone marrow of the newborn mice.

Table 1. Showing\% of polychromatic erythrocytes (PCE's) with micronuclei in 6000 bone marrow cells of mice, 24 hr after the last oral treatment with different doses of fluconazole.

\begin{tabular}{|c|c|c|c|c|}
\hline Treatment with fluconazole & Number of PCE's & $\%$ PCE's & Number of PCE's with micronuclei & $\%$ of PCE's with micronuclei \\
\hline Control & 978 & 16.30 & 14 & 1.43 \\
\hline $25 \mathrm{mg} / \mathrm{kg}$ bw/day & 886 & 14.77 & $23^{*}$ & $2.60 *$ \\
\hline $50 \mathrm{mg} / \mathrm{kg} \mathrm{bw} / \mathrm{day}$ & $700^{*}$ & $11.67^{*}$ & $65^{*}$ & $9.29 *$ \\
\hline
\end{tabular}

*Significantly different from the control $\mathrm{P}<0.05$.

\subsubsection{Chromosomal Aberrations}

Normally, the chromosomes in the mouse are acrocentric, and diploid $(2 \mathrm{n}=40)$. After 5 weeks of treatment with 50 and $100 \mathrm{mg} / \mathrm{kgbw}$ of fluconazole, the incidence of numerical and structural chromosomal aberrations was significantly increased (Table 2, Figures 1-3). The most abundant type of numerical chromosomal aberrations because of the treatment of $100 \mathrm{mg} / \mathrm{kgbw}$ doses of fluconazole was hypoploidy and deletion (Table 2, $P \leq 0.001$; Figure 3). On the other hand, fluconazole at a dose of $25 \mathrm{mg} / \mathrm{kgbw}$ showed insignificant numerical chromosomal aberrations. The frequency of structural chromosomal aberrations in bone marrow cells following treatment with 50 and $100 \mathrm{mg} / \mathrm{kgbw}$ dose levels of fluconazole also showed a significant increase compared with $25 \mathrm{mg} / \mathrm{kgbw}$ and control group. The varieties of structural chromosomal aberrations that induced by the treatment with 50 and $100 \mathrm{mg} / \mathrm{kgbw}$ dose doses of fluconazole were deletion, centric fusion, and stickiness (Table 2, Figures 2, 3). In general, deletion and centric fusion 
appeared to be more than stickiness.

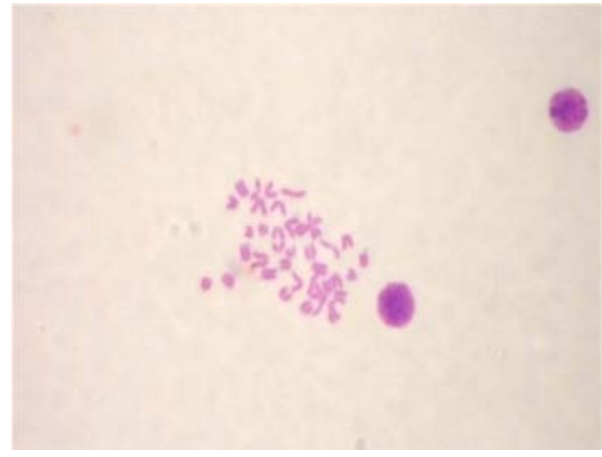

Figure 1. Showing the normal chromosomal appearance in the bone marrow cells of normal mice, $X 1000$.

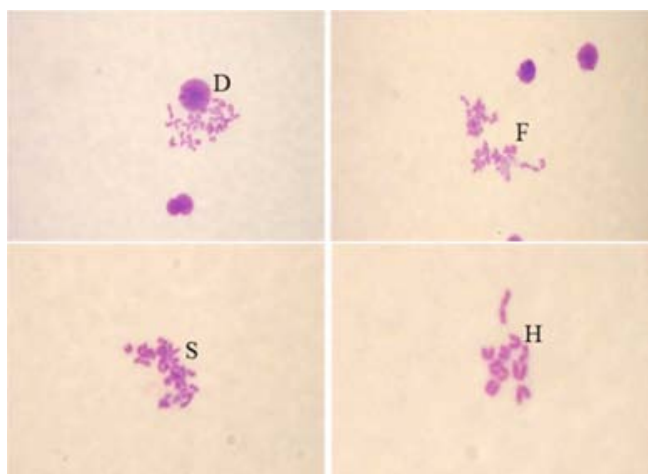

Figure 2. Showing structural chromosomal aberration in mice administered with $50 \mathrm{mg} / \mathrm{kg} b w /$ day fluconazole, Note: D: deletion (D); F: fusion; $S$ : stickiness; H: hypoploidy, X 1000.

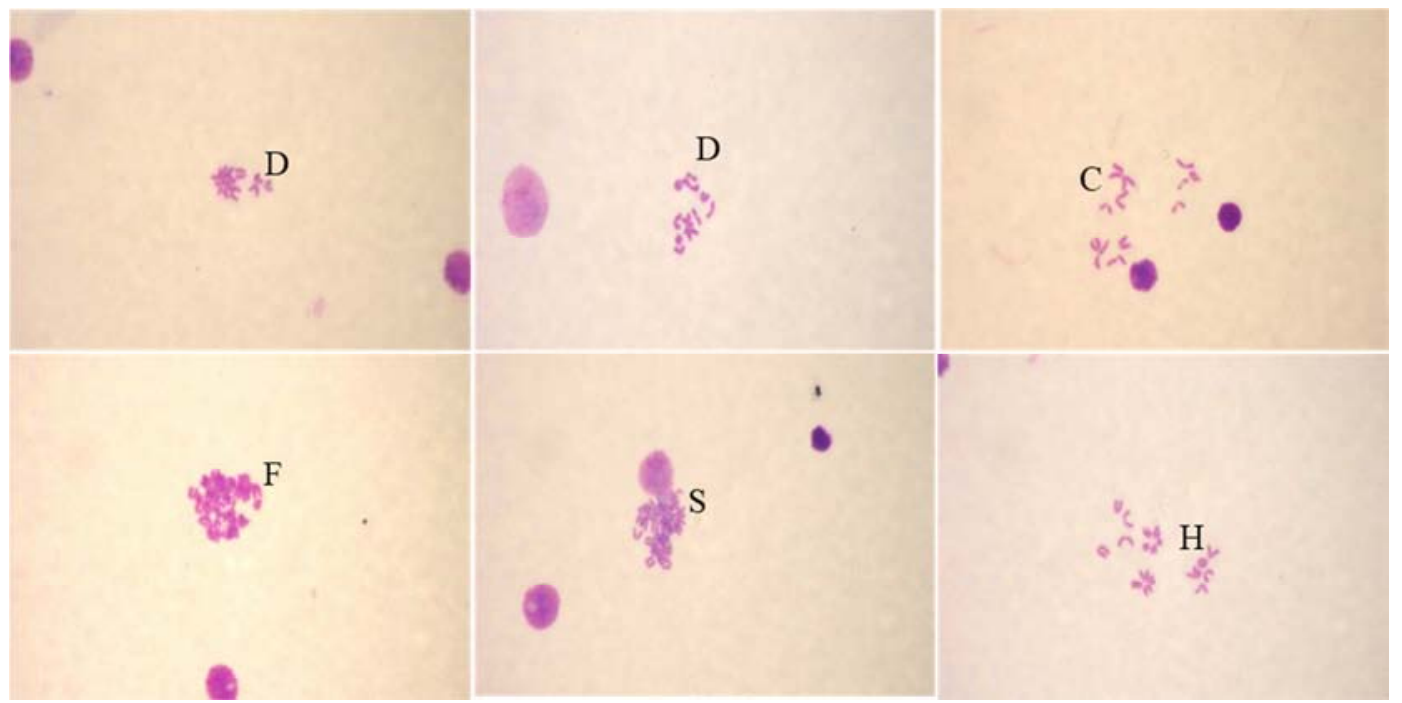

Figure 3. Showing structural chromosomal aberration in mice administered with $100 \mathrm{mg} / \mathrm{kg} b w /$ day fluconazole, showing: D: deletion (D); cf: centric fusion; $S$ : stickiness; H: hypoploidy, X 1000.

Table 2. Showing\% of chromosomal aberrations in 180 bone marrow cells of mice $24 \mathrm{hr}$ after the last oral treatment with different doses of fluconazole.

\begin{tabular}{|c|c|c|c|c|c|c|}
\hline \multirow{2}{*}{$\begin{array}{l}\text { Treatment with } \\
\text { fluconazole }\end{array}$} & \multirow{2}{*}{$\begin{array}{l}\text { No. of abnormal } \\
\text { metaphases }\end{array}$} & \multicolumn{4}{|c|}{ Number of metaphases with } & \multirow{2}{*}{$\begin{array}{l}\text { \% of total aberrant } \\
\text { metaphases }\end{array}$} \\
\hline & & Deletion & Centric fusion & Stickiness & Hypoploidy & \\
\hline Control & 6 & 1 & 2 & - & 3 & 3.3 \\
\hline $25 \mathrm{mg} / \mathrm{kg}$ bw/day & 12 & 3 & 4 & - & 5 & 6.7 \\
\hline $50 \mathrm{mg} / \mathrm{kg}$ bw/day & 57 & 17 & 15 & 10 & 15 & 31.7 \\
\hline $100 \mathrm{mg} / \mathrm{kg}$ bw/day & 74 & 22 & 18 & 11 & 23 & 41.1 \\
\hline
\end{tabular}

"Significantly different from the control $\mathrm{P}<0.05$.

\subsection{Histopathology}

\subsubsection{Light Microscopic Findings}

Light microscopic examination of sections of the liver of control mice showed the normal lobulation. The hepatocytes were closely adjacent and compactly arranged in branching cords. They usually single cell layer thick and radiated from the central vein to the periphery. The hepatic cords were separated from each other by large vascular spaces called hepatic sinusoids. The hepatocytes were polygonal in shape, having rounded-shaped nuclei and contain one or two prominent nucleoli. The binucleated hepatocytes and the Kupffer cells are clearly shown. Evidence of mild damage was noticed after treatment with $25 \mathrm{mg} / \mathrm{kgbw} /$ day fluconazole for 5 consecutive weeks. Most hepatocytes appeared in the normal morphological appearance as in the control, however, disorganized hepatocytes, binucleated hepatocytes, dilated sinusoids and activated Kupffer cells were observed. Administration with $50 \mathrm{mg} / \mathrm{kgbw} / \mathrm{day}$ fluconazole showed that the hepatic architecture had lost their usual arrangement of hepatic strands, and congestion in the central vein was observed. Also, cytoplasmic vacuolation in most hepatocytes was observed. However, extensive hepatocellular necrosis, degeneration in peri-acinar zona, hyperplasia of bile ducts including biliary cirrhosis and granuloma of binucleated and giant cells were noticed in the 
hepatic tissues of mice taken $100 \mathrm{mg} / \mathrm{kgbw} /$ day fluconazole. Severe congestion in the central veins, dilatation in the central veins, and a massive densely packed lymphocytic infiltration were also observed (Figure 4).

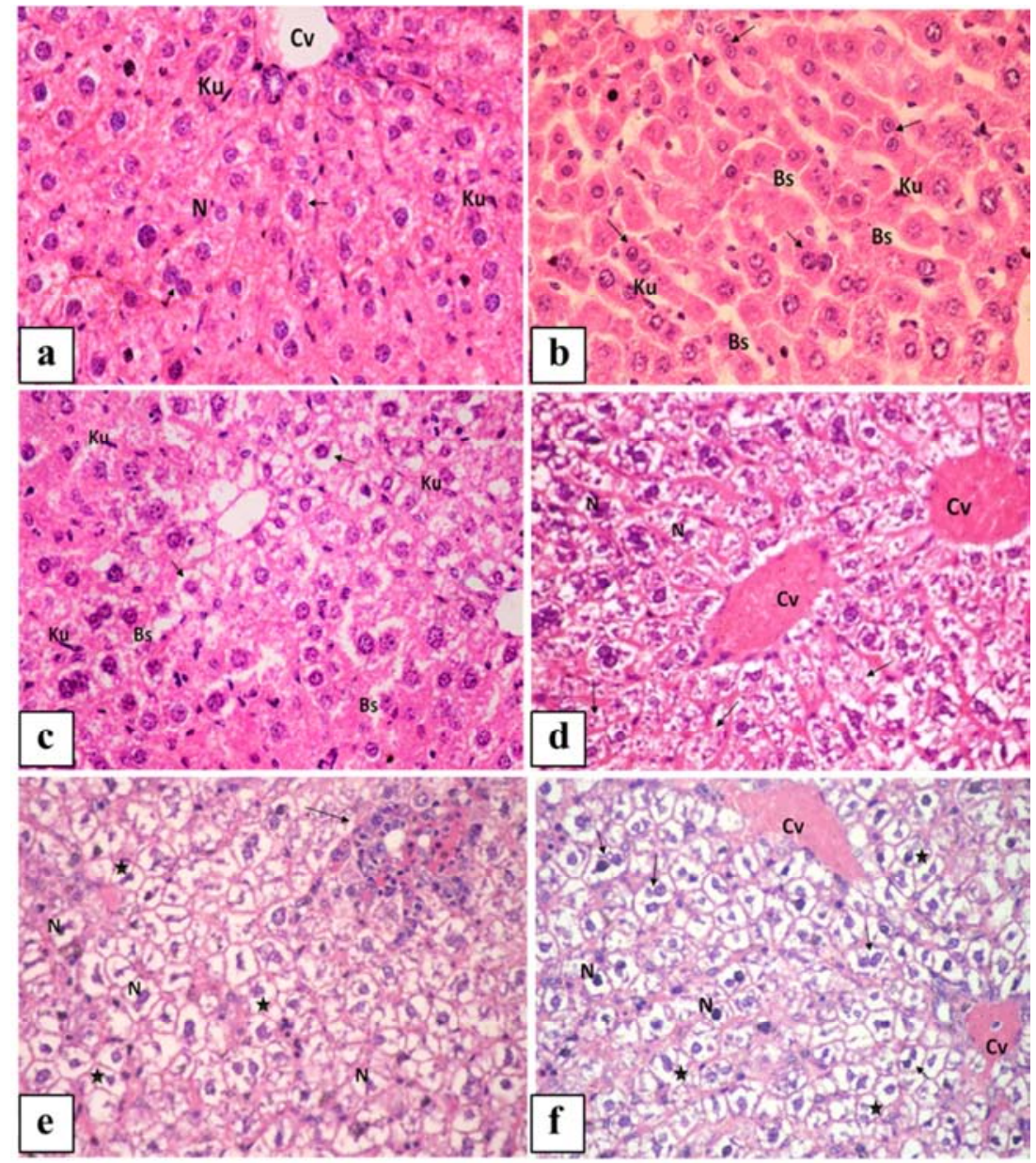

Figure 4. (a-f): Sections of liver mice, showing; a: in control mice showing hepatocytes are radiated from the central veins (Cv); the hepatocytes have centrally-located basophilic nuclei (N); binucleated cells (arrows); Kupffer cells (Ku); b: in mice treated with $25 \mathrm{mg} / \mathrm{kg}$ bw/day fluconazole, showing mildly disorganized hepatocytes, binucleated hepatocytes (arrows), dilated sinusoids (Bs), Kupffer cells (Ku); $c$ \& d: in mice treated with $50 \mathrm{mg} / \mathrm{kgbw} / \mathrm{day}$ fluconazole showing vacuolation in the cytoplasm of hepatocytes (arrows), pyknotic hepatocyte nuclei $(N)$ ); congestion of the in central veins (Cv); $e \& f:$ in mice treated with $100 \mathrm{mg} / \mathrm{kgbw} /$ day fluconazole showing severe vacuolation in hepatocytes, pyknotic hepatocyte nuclei (*); massive lymphatic infiltration (arrow). $H \& E, X 400$.

\subsubsection{Electron Microscopic Findings}

Under the electron microscope, the hepatocytes of the liver tissue of control mice showed the appearance of large centrally placed nuclei with the distinct nuclear envelope and prominent nucleoli. In the cytoplasm, the mitochondria were of different shapes and sizes, they were mostly bounded by inconspicuous mitochondrial membranes and their cristae were not prominent. Few scattered primary lysosomes and few small lipid droplets could be seen. Space of Disse was recognized as a narrow space between the endothelial cells and the surface of hepatocytes.

The electron micrographs of liver sections of mice treated with $25 \mathrm{mg} / \mathrm{kgbw} /$ day fluconazole showed an abundant amount of electron-lucent lipid droplets was observed in the cytoplasm of most hepatocytes. The mitochondria appeared swollen, and short profiles of the interrupted rough endoplasmic reticulum were seen with no close relationship with the mitochondria. In addition to a marked increase in the proliferative amount of smooth endoplasmic reticulum was noticed, indicating the toxic effect of fluconazole, and few short micro-villous projections in the dilated sinusoidal space were seen in, while others devoid them.

While the electron micrographs of liver cells of mice treated with $50 \mathrm{mg} / \mathrm{kgbw} /$ day fluconazole revealed nuclear pyknosis. Few cisternal disruptions of the rough endoplasmic reticulum (rER) and no close association between the mitochondria and rER were observed. The mitochondria exhibited an irregular configuration; possessed dense matrices, and some showed bizarre forms. Furthermore, a few numbers of small light lipid droplets could be seen.

The electron micrographs of hepatocytes of mice administered with $100 \mathrm{mg} / \mathrm{kgbw} /$ day of fluconazole exhibited an appearance of many pyknotic nuclei of hepatocytes, and in others contained more than one proliferating nucleoli, indicating their active changes. The mitochondria showed a marked loss in their matrix and revealed a large degree of polymorphism. The rER was greatly reduced into few short 
irregularly placed cisternae, partially surrounding the nuclei. Many small dense lysosomal particles and an increase in the

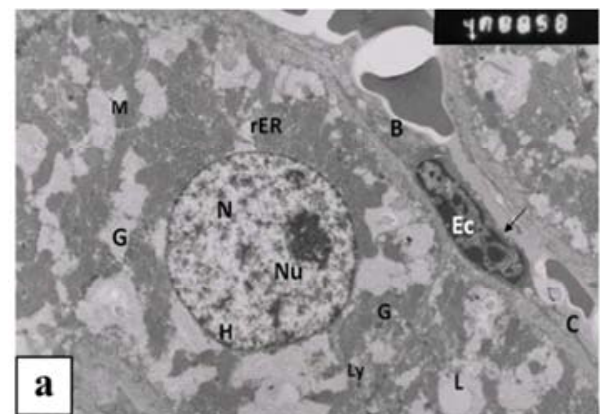

number and size of light electron density lipid droplets were observed (Figure 5).
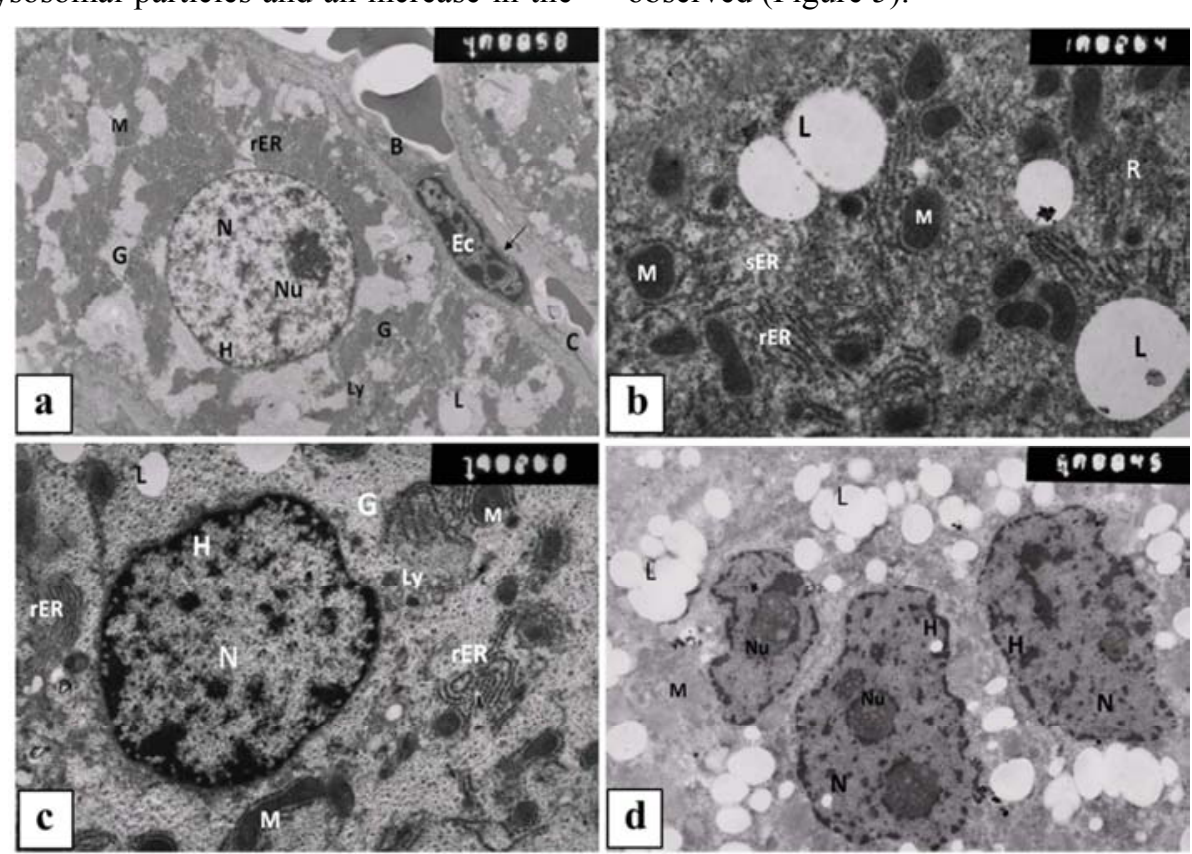

Figure 5. (a-d): Electron micrographs of the liver: a: in control mice showing the hepatocyte nucleus (N); nucleolus (Nu), heterochromatin (H), mitochondria $(M)$; short arrays of the rough endoplasmic reticulum ( $r E R)$, $\beta$-glycogen particles $(G)$; space of Disse (arrow); capillary $(C)$ and blood cell $(B)$. X 4000; $b$ : in mice treated with $25 \mathrm{mg} / \mathrm{kgbw} /$ day fluconazole showing swollen mitochondria $(M) ; r E R$, lipid droplets (L), ribosomal particles $(R)$, smooth endoplasmic reticulum (sER) X10000; $c$ : in mice treated with $50 \mathrm{mg} / \mathrm{kgbw} /$ day fluconazole showing an irregular-shaped hepatocyte nucleus (N); mitochondria (M); disruption cisternae of $r E R$, primary lysosomes $(L y)$; accumulation of $\beta$-granules of glycogen $(G)$; few lipid droplets $(L)$. X 7500; d: in mice treated with 100 $\mathrm{mg} / \mathrm{kgbw} /$ day fluconazole showing pyknotic hepatocytes nuclei $(N)$ containing enlarge nucleoli, mitochondria with indistinct matrix $(M)$, lipid droplets (L). $X$ 5000

\subsubsection{DNA Fragmentation}

By applying polyacrylamide gel electrophoresis for analysis of DNA in the liver tissue, the results showed no difference in the DNA bands between control and different doses of fluconazole-treated mice (Figure 6).

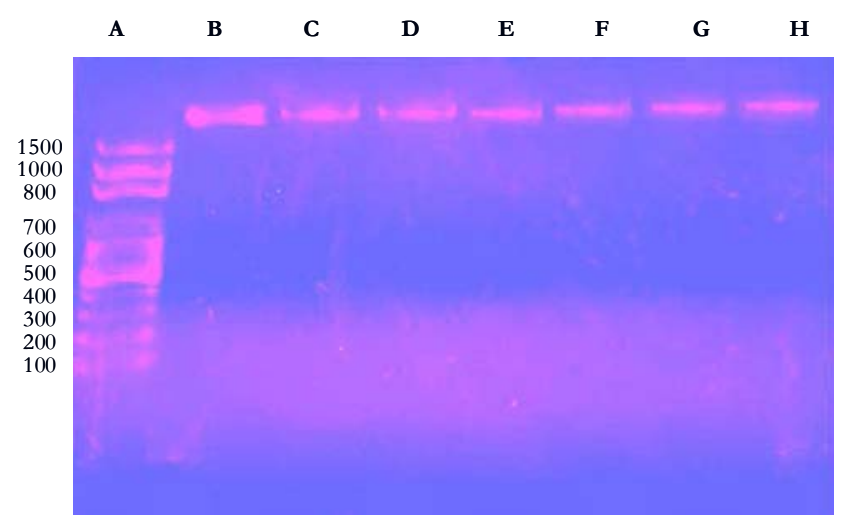

Figure 6. Gel electrophoresis photograph shows the genomic DNA of liver tissue from control and treated groups, showing Lane A: DNA marker; Lane B: Control; Lane C, D: Dose 1 (25 mg/kgbw); Lane E, F: Dose 2 (50 $\mathrm{mg} / \mathrm{kgbw})$; Lane $\mathrm{G}, \mathrm{H}$ : Dose 3 (100 $\mathrm{mg} / \mathrm{kgbw})$.

\section{Discussion}

As a potent antifungal drug, fluconazole has been clinically used in the treatment of mycoses causing hepatotoxicity, therefore, the objective of the current study was to evaluate hepatotoxicity and genotoxicity in newborn mice. Based on genotoxicity levels observed in the present findings, fluconazole had the highest hazard in prompting micronucleus and chromosomal aberrations by a dose of $50 \mathrm{mg} / \mathrm{kg}$ and $100 \mathrm{mg} / \mathrm{kg}$ fluconazole for five consecutive weeks. Moreover, as it was reported by Sun et al. [24], fluconazole did not affect the body weight of mice compared with the control mice.

Concerning the micronucleus test, the results revealed an increase in the percentage of polychromatic erythrocytes of mice bone marrow cells taken $50 \mathrm{mg} / \mathrm{kgbw}$ and 100 $\mathrm{mg} / \mathrm{kgbw}$ fluconazole, in comparison with $25 \mathrm{mg} / \mathrm{kgbw}$ and control group. This indicates that fluconazole could interfere with the nuclear division of the bone marrow cells in such a way that chromatin fragments or whole chromosome had lagged at anaphase and did not incorporate into one of the daughter nuclei at the time of the cell division [25]. Hypoploidy, deletion, centric fusion, and stickiness was the manifestation of structural and numerical aberrations at doses of $50 \mathrm{mg} / \mathrm{kgbw}$ and $100 \mathrm{mg} / \mathrm{kgbw}$ while $25 \mathrm{mg} / \mathrm{kgbw}$ dose of fluconazole was not harmful to bone marrow cells. These findings indicate the absence of incidence of systemic toxicity at a dose of $25 \mathrm{mg} / \mathrm{kgbw}$. Yuzbasioglu et al. [17] declared that fluconazole could induce structural chromosomal abnormalities as in a state of chromatid and chromosome breaks as well as sister chromatid union. While 
Biswas et al. [26] reported that breaking in the chromosomal aberration may attribute possibly to that the chemicals acted after chromosome duplication at the G2 phase of the cell cycle. Stickiness might be attributed to an action on the proteins of chromosomes [27]. The mechanism of chromosomal aberrations has been shown by Michailova et al. [28]. who explained that the chromosomal aberrations might be due to the consequence of processes which operate on damage induced by different factors in chromosomal DNA.

The antifungal drug, fluconazole caused dose-dependent micronucleus aspects for bone marrow polychromatic erythrocytes (PCEs). The PCEs is an indicator of the acceleration or inhibition of erythropoiesis and varies with the scoring interval. The increase in the PCEs percentage may indicate the suppression of cell division, the damage of erythroblasts, the addition of damaged cells, or exceed of the existing cell pool with newly deformed cells [29].

Various mechanistic interpretations may contribute to the genotoxicity and cytotoxicity of fluconazole induction [30], including of fluconazole in cellular DNA [31], the stability of the topoisomerase II-DNA complex [32] free radicalmediated toxicity caused by fluconazole [33], or the generation of reactive oxygen species (ROS) by the fluconazole [34].

50 and $100 \mathrm{mg} / \mathrm{kgbw}$ fluconazole showed certain histopathological alternations in the hepatic tissues of mice, where there was marked disorganization of the parenchymal cells and the presence of vacuoles might be the starting point of the cellular autolytic process. Moreover, $100 \mathrm{mg} / \mathrm{kgbw} /$ day fluconazole revealed severe dilatation and congestion of central veins and hepatic sinusoids in most of the hepatic tissue, and there were hydropic hepatocytic and lymphocytic infiltrations.

Indeed, the incidence of the hepatotoxicity during treatment with fluconazole has been described in several types of research followed by a compilation of interpreted reports on the mechanisms of hepatotoxicity induced by antifungal agents [35]. Shubin et al. [36] explained that the vacuolation of hepatocytes was most probably due to the retention of fluid inside the hepatocytes. Furthermore, it was reported that the swelling of hepatocytes results in hydropic degeneration which was due to reduction of the energy necessary for regulation of ion concentration of the cells or short term anoxia or metabolic stress [37, 38]. Jensen et al. [39] suggested that such cellular infiltration might be due to the presence of necrotic cells which act as an irritant substance attracting the inflammatory cells. In this context, the current results are consistent with the suggestion of Chen et al. [40] who stated that the patches of aggregation of inflammatory cells infiltration could be a defence mechanism of the liver against the toxic effect of the drug.

About the ultrastructure of hepatotoxicity, the accumulation of an abnormal amount of fat in the hepatic parenchymal cells is a sign of injury and could be attributed to impaired protein synthesis as a result of rER damage and accordingly inhibition of lipoprotein manufacture [41].
Consistent with the present results the hepatic alterations after antifungal drug fluconazole administration may be correlated with defects on all cell organelles and membranes in addition to the marked proliferation of smooth endoplasmic reticulum and presence of few microbodies and numerous defects on mitochondria in the hepatocytes [42]. Further, in the present results, $100 \mathrm{mg} / \mathrm{kgbw} /$ day dose of fluconazole showed mitochondrial swelling, displayed electron less dense matrices and a large degree of polymorphism suggesting sensitive cell injury. As such results could be attributed to the accumulation of fluid in the mitochondrial matrix which in turn destroyed the cristae. Since the mitochondria are the site of the main energy production of the cell, their damage may result in lowered energy output [13]. Somchit et al [43] reported that disruption of the whole hepatocytes rather than inhibition of mitochondrial respiration.

Furthermore, the dilatation and destruction of rough endoplasmic reticulum and loss of adhering ribosomes are considered as the rER in liver cells the main target of many chemical agents and due to it is also participating in the metabolism of various drugs and poisons. Again, rough endoplasmic reticulum and its damage represent the main site of protein synthesis in the cells; such damage could be reflected in the impaired capacities of such cells in protein synthesis [44].

In the present results, DNA laddering electrophoresis revealed that fluconazole did not affect the quality of DNA in any dose levels compared to the control. This was confirmed by the results of [45] who found that fluconazole had no observable damage in the genome of adult animals (8weeks old), and causes a high increase in micronuclei frequency in young animals ( 3 weeks old), and in newborn pups.

\section{Conclusion}

The current assessment indicates that fluconazole toxicity mainly hepatoxicity occurring in two diagnostic forms, that is, genotoxicity and histopathology, distinctly promotes micronuclei formation, chromosomal aberrations, and hepatocellular deterioration in vivo in newborn male mice. Indeed, Micronucleus, chromosomal aberrations (numerical and/or structural) is certainly a key factor in the genotoxicity progression of organ disorders.

\section{Disclosure of Financial and Competing Interest}

The authors have no financial participation with any entity or organization with a financial benefit or financial conflict concerned with the materials or subject matter for this manuscript. Also, no assistance was utilized in writing and the production of the present manuscript.

\section{Funding}

There is no personal Funding or supported grant from any 
Foundation.

\section{Conflicts of Interest}

The authors declare that there is no conflict of interests.

\section{Authors' Contributions}

Azza Attia, Elhenshery Z. M. conceived and designed the study and also performed the experiments, photomicrographs (light and electron microscopy) and collected the data. Reda ElMazoudy wrote the primary manuscript. Matta C. A. provided her expertise and reviewed the manuscript.

\section{References}

[1] Talaro KP. Foundations in microbiology. $6^{\text {th }}$ ed. McGraw-Hill Company. American, New York, NY. 2008.

[2] Vanhoutte I, Audenaert K, De Gelder L. Biodegradation of Mycotoxins: Tales from Known and Unexplored Worlds. Front Microbiol. (2016) 7: 561-569.

[3] Almirante B, Rodriguez D. Antifungal Agents in Neonates, Issues and Recommendations. Pediatr. Drugs. (2007) 9 (5): 311-321.

[4] Morrell M, Fraser VJ, Kollef MH. Delaying the empiric treatment of Candida bloodstream infection until positive blood culture results is obtained: a potential risk factor for hospital mortality. Antimicrob Agents Chemother. (2005) 49: 3640-3645.

[5] Francois I E, Cammue B P A, Borgers M, Ausma J, Dispersyn GD, Thevissen K. Azoles: Mode of antifungal action and resistance development. Med. Chem. (2006) 5: 3-13.

[6] Somchit N, Norshahida AR, Hasiah AH, Zuraini A, Sulaiman MR, Noordin MM. Hepatotoxicity induced by antifungal drugs itraconazole and fluconazole in rats: a comparative in vivo study. Human \& Experimental Toxicology. (2004) 23: 519-525.

[7] Abdel-Mottaleb MM, Mortada ND, Elshamy AA, Awad GA. Preparation and evaluation of fluconazole gels. Egypt. J. Biomed. Sci. (2007) 3: 266-286.

[8] Girish, M. B. and Patil, P. A. 2005. The influence of some azoles on wound healing in albino rats. Indian J. Pharmacol., 37 (4): $247-250$.

[9] Leonart LP, Tonin FS, Ferreira VL, Suelem TSi, Fábio de Araújo M, Roberto P. Safety and efficacy of different doses of fluconazole used for invasive prophylaxis of fungal infection in neonates. J. Pediatric. (2017) 185: 129-135.

[10] Lollis TR, Bradshaw WT. Fungal prophylaxis in neonates: a review article. Adv. Neonatal Care, 2014; 14 (1): 17-23.

[11] Tully DB, Bao W, Goetz AK, Blystone CR, Ren H, Schmid JE, Strader LF, Wood CR, Best DS, Narotsky MG, Wolf DC, Rockett JC, Dix DJ. Gene expression profiling in liver and testis of rats to characterize the toxicity of triazole fungicides. Toxicol. Applied Pharmacol. (2006) 215: 260-273.

[12] Peffer RC, Moggs JG, Pastoor T, Currie RA, Wright J,
Milburn G, Waechter F, Rusyn I. Mouse liver effects of cyproconazole, a triazole fungicide: role of the constitutive androstane receptor. Toxicol. Sci. (2007) 99: 315-325.

[13] Vincent AE, Ng YS, White K, Davey T, Mannella C, Falkous G, Feeney C, Schaefer AM, McFarlan, R, Gorman GS, Taylor RW, Turnbull DM, Picard M. The spectrum of mitochondrial ultrastructural defects in mitochondrial myopathy. Sci Rep. (2016) 6: 30610 .

[14] Fenech M. The in vitro micronucleus technique. Mutation Research (2000) 455: 81-95.

[15] Prenkumar K., Bowlus CL. Ascorbic acid reduces the frequency of iron-induced micronuclei in bone marrow cells of mice. Mutat. Res. (2003) 542: 99-103.

[16] Schmid W. The Micronucleus test. Mut. Res. (1975) 31: 9-15.

[17] Yuzbasioglu D, Unal F, Yilmaz S, Aksoy H, Celik M. Genotoxicity testing of fluconazole in vivo and in vitro. Mut. Res. (2008) 649: 155-160.

[18] Gisselsson D, Bjork J, Hoglund JM, Mertens F, Dal Cin P, Akerman M, Mandahl N. Abnormal nuclear shape in soild tumors reflects mitotic instability. Am. J. Pathol. (2001) 158: 199-206.

[19] Holeckova B, Dianovsky J, Sivikova K, Mesarc M. Detection of chromosomal aberrations in cattle cells after conazole fungicide treatment. Toxicology. (2010) 196S: S37-S351.

[20] Preston RJ, Kean BJ, Galloway S. Mammalian in vivo cytogenetic assays: Analysis of chromosome aberrations in bone-marrow cells. Mutat. Res. (1987) 198: 157-165.

[21] Saad HG, Dalvai F, Tanguy-le-Gac, M, Lane, N, Bystricky, K. DNA Dynamics during Early Double-Strand Break Processing Revealed by Non-Intrusive Imaging of Living Cells. PLoS Genet. (2014) 10 (3): e1004187.

[22] Bancroft JD. Theory and practice of histological techniques. $4^{\text {th }}$ ed. Churchill Li veinstone, 1996.

[23] Bozzola, JJ, Russell, LD. Electron microscopy, $2^{\text {nd }}$ ed. Jones and Bartlett publishers, 1998.

[24] Sun G, Thai SF, Lambert GR, Wolf DC, Tully DB, Goetz AK, George MH, Grindstaff RD, Dix DJ, Nesnow S. Fluconazoleinduced hepatic cytochrome P450 gene expression and enzymatic activities in rats and mice. Toxicol. Lett. (2006) 164: 44-53.

[25] Potapova T, Gorbsky GJ. The consequences of chromosome segregation errors in mitosis and meiosis. Biology (2017) 6: $12-22$.

[26] Biswas SJ, Pathak S, Khuda-Bukhsh AR. Assessment of the genotoxic and cytotoxic potential of an anti-epileptic drug, Phenobarbital, in mice: a time course study. Mut. Res. (2004) 563: $1-11$.

[27] Badr A. Cytogenetic activities of 3 sulphonamides. Mut. Res. (1982) 104: 95-100.

[28] Michailova P, Petrova N, Bovera S, Cavicchioh O, Ramella L Sella G. Effect of environmental pollution on the chromosomal variability of chironomus riparius meigen, 1804 (Diptera, chironmidae) Larvae From two Predmont Stations. Genetica. (2000) 108: 171-180. 
[29] Oller AR, Erexson G. Lack of micronuclei formation in bone marrow of rats after repeated oral exposure to nickel sulfate hexahydrate. Mutat. Res. (2007) 626 (1-2): 102-110.

[30] Harrison BD, Hashemi J, Bibi M, Pulver R, Bavli D, Nahmias Y, Wellington M, Sapiro G, Berman JA. Tetraploid intermediate precedes aneuploid formation in yeasts exposed to fluconazole. PLoS Biol., 2014; 12: e1001815.

[31] Correa RM, Mota TC, Guimarães AC, Bonfim LT, Burbano RR, Bahia MO. Cytotoxic and Genotoxic Effects of Fluconazole on African Green Monkey Kidney (Vero) Cell Line. Biomed. Res. Int. (2018) 6271547.

[32] Jain CK, Majumder HK, Roychoudhury S. Natural compounds as anticancer agents targeting DNA topoisomerases. Curr Genomics. (2017). 18: 75-92.

[33] Dbouk ND, Covington MB, Nguyen K, Chandrasekaran S. Increase of reactive oxygen species contributes to growth inhibition by fluconazole in Cryptococcus neoformans. Microbiology. (2019) 19: 243-253.

[34] Peng CA, Gaertner AAE, Henriquez SA, Fang D. ColonReyes, R. J. Brumaghim J. L. and Kozubowski, L. Fluconazole induces ROS in Cryptococcus neoformans and contributes to DNA damage in vitro, PLoS One. (2018) 13: $\mathrm{e} 0208471$.

[35] Khoza S, Ishmael M, Denver N. Comparative Hepatotoxicity of Fluconazole, Ketoconazole, Itraconazole, Terbinafine, and Griseofulvin in Rats. J. Toxicol. (2017) 9-18.

[36] Shubin AV, Demidyuk AA, Komissarov et al. Cytoplasmic vacuolization in cell death and survival. Oncotarget. (2016) 7: 55863-55889.

[37] Emam H, Ahmed E, Abdel-Daim M. Antioxidant capacity of omega-3-fatty acids and vitamin $\mathrm{E}$ against imidacloprid- induced hepatotoxicity in Japanese quails. Environ Sci Pollut Res. (2018) 25: 11694-11702.

[38] Vohra P, Khera KS. Alterations in key enzymes and micromorphology of vital organs during exposure of imidacloprid in albino rats. Int J. (2015) 3: 134-144.

[39] Jensen HK. et al. Presence of intratumoral neutrophils is an independent prognostic factor in localized renal cell carcinoma. J. Clin. Oncol. (2009) 27: 4709-4717.

[40] Chen L, Deng H, Cui H, Fang J, Zuo Z, Deng J, Li Y, Wang X, Zhao L. Inflammatory responses and inflammation-associated diseases in organs. Oncotarget. (2018) 9: 7204-7218.

[41] Ozkorkmaz EG, Gul N, Ozluk A, Ozay Y. Ultrastructural Alterations of Liver Tissue Cells in Methotrexate-Treated Balb/c Mice. J Microsc Ultrastruct. (2018) 6 (4): 192-196.

[42] Łotowska JM, Sobaniec-Łotowska1 ME, Sobaniec P, Lebensztej DM, Liver sinusoidal endothelial cells in morphogenesis of pediatric autoimmune hepatitis. Ultrastructural characteristics-a novel report. Pol. J. Pathol. (2018) 69 (4): 327-334.

[43] Somchit N, Ngee CS, Yaakob A, Zuraini AZ, Zakaria ZA. Effects of cytochrome P450 inhibitors on itraconazole and fluconazole induced cytotoxicity in hepatocytes. J. Toxicol. (2009) 912320: 30-37.

[44] Picard M, McManus MJ, Csordás G, Várnai P, Dorn GW, Williams D, Hajnóczky G, Wallace DC. Trans-mitochondrial coordination of cristae at regulated membrane junctions. Nat Commun. (2015) 17 (6): 6259.

[45] Fucic A, Markovic D, Herceg Z, Gamulin M, Katic J, Stojkovic R, Ferencic Z, Mildner B, Jazbec AM, Dobranic T. Developmental and transplacental genotoxicology: Fluconazole. Mut. Res. (2008) 657: 43-47. 